\title{
Strategy for Implementing Blended Learning With Google Classroom during the COVID-19 Pandemic Era in Higher Education
}

\author{
Nurul Zuriah* \\ University of Muhammadiyah Malang \\ zuriahnurul@gmail.com
}

\begin{abstract}
This paper explains the strategy of implementing blended learning with Google Classroom in the Covid-19 pandemic era in improving the learning independence and critical thinking skills of students in the PPKn (civic education) Lesson Planning course in Higher Education. The research subjects were the first-semester PPKn students of class 2018/2019, University of Muhammadiyah Malang. Data were collected using questionnaires, observation, documentation, assignments, and tests. The framework used was classroom action research with the KemmisTaggart cycle model. The study stages were divided into three cycles, with each cycle consisting of four steps: planning, implementing actions, observing, and reflecting - data analysis using qualitative descriptive analysis. The research findings resonate closely with other researchers in developed countries, which shows that the application of blended learning with Google Classroom has proven successful in increasing the students' learning independence and critical thinking. Students' ability to learn independently before blended learning was $\mathbf{1 7 . 1 4 \%}$, and after the last cycle, it increased to $90.027 \%$. Initially, students' critical thinking skills were $25.29 \%$, which rose to $90.37 \%$ after blended learning.
\end{abstract}

Keywords: blended learning, Google classroom, learning independence, critical thinking, learning achievement.

\section{INTRODUCTION}

The spread of the Coronavirus (COVID-19) has caused confusion, uncertainty, and sadness for humanity throughout the world. COVID--19 was originated from Wuhan China since the end of January 2020. The World Health Organization (WHO) has classified the phenomenon as a pandemic [1][2]. Pandemics occur when infectious diseases spread rapidly from human to human in various places throughout the world. The spread of Covid-19 continues to experience a massive surge in several countries. The COVID-19 virus can attack the respiratory system [1], [2]. The spread of
COVID-19 in various countries has forced the world community to see that the world is changing. The COVID-19 pandemic has forced people to change the meaning, patterns of life, and everyday life [3], [4]. During these fast-paced situations, endless work to pursue economic growth and achievement targets with competency requirements. However, the impact of the spread of the COVID19 virus has caused a significant crisis for modern humans today, they are urged to stop breathing for a moment to look back at family life, and the social environment of the community in the true sense. They are also forced to break their daily routine and return to what they have to look for from the true meaning of life. It then becomes a challenge for all humanity in the world [4], [5]. More countries are making new policies to anticipate the effects of the COVID-19 virus. In the education field, all countries are trying to make the best policies for the integrity of education services [6]. New policies are made to change the learning mode. Previously, learning was conducted in the classroom, but now it is carried out at home [6], [7]. The government asks people to stay at home and practice physical and social distancing, which transforms face-to-face learning mode into online learning [8], [9]. The policy was made to avoid the spread of the COVID -19 viruses in the community. The World Health Organization uses several terms, namely social distancing, physical distancing, quarantine, and isolation. In Indonesia, this is called PSBB (Large Scale Social Restriction) [10]. Online learning has potential, including meaningful learning, easy access, and improving learning outcomes. In the context of online learning, students can relate quickly and directly with text, images, sound, data, and two-way video, with teacher guidance [8], [11] [12]. Face-to-face learning has now been replaced with technology-assisted learning, which is expected to improve students' learning outcomes during this pandemic situation 8], [9], [13]. Cotton reviewed 59 research results on computer-assisted learning and learning outcomes. Studies that focus on technology are better than studies that discuss the impact of technology on the overall learning environment and student learning outcomes. Thus, web technology assistance that follows the tutorial process will increase student achievement because 
the students master the materials and technology [7] [14]. The need for social and physical distancing forms the basis of the education system by learning from home utilizing the Internet. These situations affect educators, students, and parents [ 7], [9], [11]. Many educators feel panic and shock because they have to change their teaching methods, systems, and models into online learning. Frequently, it is not supported by adequate facilities in its implementation. This phenomenon is a record for the world of education, which demands that teachers be more prepared to teach and learn online. The new method requires competence, accuracy, and speed. Blended learning is a learning approach that combines traditional face-to-face learning and distance learning using online resources and virtual learning with various communication options that can be used by teachers and students [15], [16], [17]. A blended learning method is a mixture of face-to-face meetings and online learning [18], [19]. This can also be used to maximize the advantages of the two methods. Blended learning is beneficial for students, especially in mastering well the concept of learning [15], [17], [20]. Blended learning can improve student performance too [21], [22], [23]. In terms of media that educators use in online education, virtual classes with Google Classroom (GC) are one of the most frequently used. Google Classroom is a product from Google that develops free LMS. It is a mixed learning platform designed to help educators design, share, and classify materials, assignments/instructions, and paperless questionnaires. Google Classroom has several advantages: a fast and convenient setup process, efficiency, collaboration and communication, centralized data storage, and quick resource sharing. Google Classroom is a free online service for schools, non-profit organizations, and anyone with a Google account [7], [24]. With Google Classroom, students and teachers can stay connected inside and outside the classroom. It is a combined or mixed learning model [7], [25], [26]. This research is based on the observations on students majoring in Civic Education year 2019/2020 school taking PPKn Lesson Planning course. By using conventional learning, through class discussion, not all students were actively involved in expressing their opinions based on topics given by the lecturer. Of the 28 students, only five students seemed to understand the practice of lesson planning in school. This condition shows that students have not been able to learn independently about the course materials. Besides, this phenomenon also shows that students have not been able to think critically about the implementation of the PPKn lesson planning in actual schools. Some of the problems above require viable solutions so as not to interfere with the learning process and outcome. Blended learning with Google Classroom was carried out by the researcher as a learning method in the current Covid-19 pandemic era.

\section{METHOD}

This study used classroom action research by adopting a cycle model action research from Kemmis and McTaggart [27], [28]. The research was conducted in three cycles, with each cycle consisting of four stages: planning, implementing, observing, and reflecting. Blended learning activities using Google classroom would continue until the next period if indicators of success have not been achieved. This is in line with what Suharsimi Arikunto revealed that the number of research cycles in classroom action research depends on achieving benchmarks [29]. However, it should not be less than two cycles. This class action research was conducted on students of Civic Education Study Program in the Faculty of Teacher Training and Education, University of Muhammadiyah Malang academic year 2019/2020, who took the PPKn Lesson Planning course. The subjects of this study were 28 students. The object of this study was blended learning with Google classroom to improve students' learning independence and critical thinking ability. This research was conducted in February - May 2020. The data were collected through questionnaires, documentation, and observation. This is qualitative research so that a credibility test or reliability test of qualitative research data is essential. Data triangulation was also used in this study.

\section{RESULT \& DISCUSSION}

The learning process is considered successful and has good quality if all or at least $75 \%$ of students are actively involved and show high enthusiasm for learning and high self-confidence. Positive behavior appears in students entirely or at least $75 \%$ following established competencies [30]. The implementation of blended learning with Google classroom is deemed successful when a minimum of $75 \%$ of the students show independence in learning, critical thinking ability and obtains learning achievement of at least 75 for numerical grades. Based on the implementation of blended learning with Google Classroom in this study, the following results were obtained:

\section{Students' Learning Independence}

There are five criteria used to measure the dimensions of student learning independence. This criterion is then used as a guide to assess the number of students who have to learn independence between pre-research, cycle one, cycle two, and cycle three. Analysis Results from the Aspects of Student Learning Independence in Table 1.

Based on the data analysis presented above, it 
was found that the students' learning independence before the study was $17.14 \%$. After the 3rd cycle, blended learning with Google Classroom, it increased to $90.02 \%$. So, it can be stated that there was a significant increase in students' ability to learn independently before and after the implementation of blended learning with Google Classroom (cycle 1 , cycle 2 , and cycle 3 ).

\section{Students' Critical Thinking}

There are 13 criteria used to measure aspects of students' critical thinking. This criterion is then used as a guideline to assess the number of students who can think critically between pre-research, cycle one, cycle two, and cycle three. Analysis of Results of Critical Thinking Aspects in Table 2.

Based on the analysis of the data above, it was

Table 1. Analysis Results from the Aspects of Student Learning Independence

\begin{tabular}{|c|c|c|c|c|c|c|c|c|}
\hline \multirow[t]{2}{*}{ Criteria } & \multicolumn{2}{|c|}{ Pre-PTK } & \multicolumn{2}{|c|}{ Cycle 1} & \multicolumn{2}{|c|}{ Cycle 2} & \multicolumn{2}{|c|}{ Cycle 3} \\
\hline & $\Sigma$ & $\%$ & $\Sigma$ & $\%$ & $\Sigma$ & $\%$ & $\Sigma$ & $\%$ \\
\hline $\begin{array}{l}\text { 1. Take the initiative, either with } \\
\text { or without the help of others, } \\
\text { to dagnose their learning }\end{array}$ & 4 & 14,28 & 12 & 42,86 & 20 & 71,43 & 24 & 85,7 \\
\hline 2 Formulate learning objectives & 6 & 21,43 & 12 & 42,86 & 20 & 71,43 & 24 & 85,7 \\
\hline $\begin{array}{l}\text { 3. Identifying learning resources, } \\
\text { both human and material }\end{array}$ & 4 & 14,28 & 12 & 42,86 & 24 & 85,72 & 26 & 92,9 \\
\hline $\begin{array}{l}\text { 4. Able to choose and implement } \\
\text { learning stratcgics that arc } \\
\text { suitable for him }\end{array}$ & 6 & 21,43 & 12 & 42,86 & 24 & 85,72 & 26 & 92,9 \\
\hline 5. Evaluating the results of learning & 4 & 14,28 & 12 & 42,86 & 20 & 71,4 & 26 & 92,9 \\
\hline Average & 4,8 & 17,14 & 12 & 42,86 & 21,6 & 77,14 & 25,2 & 90,02 \\
\hline
\end{tabular}

Table 2. Analysis of Results of Critical Thinking Aspects

\begin{tabular}{|c|c|c|c|c|c|c|c|c|}
\hline \multirow[t]{2}{*}{ Criteria } & \multicolumn{2}{|c|}{ Pre-PT K } & \multicolumn{2}{|c|}{ Cycle 1} & \multicolumn{2}{|c|}{ Cycle 2} & \multicolumn{2}{|c|}{ Cycle 3} \\
\hline & $\Sigma$ & $\%$ & $\Sigma$ & $\%$ & $\Sigma$ & $\%$ & $\Sigma$ & $\%$ \\
\hline 1. Open-minded & 6 & 21,43 & 15 & 53,57 & 21 & 75 & 26 & 92,85 \\
\hline $\begin{array}{l}\text { 2. Take action when the } \\
\text { evidence and reasons are }\end{array}$ & 7 & 25 & 15 & 53,57 & 20 & 71,42 & 26 & 92,85 \\
\hline 3. Consider the whole situation & 8 & 28,57 & 15 & 53,57 & 24 & 85,71 & 25 & 89,28 \\
\hline $\begin{array}{l}\text { 3. Equip yourself with infor- } \\
\text { mation }\end{array}$ & 7 & 25 & 21 & 75 & 25 & 89,28 & 26 & 92,85 \\
\hline $\begin{array}{l}\text { 5. Look for the truth / accuracy } \\
\text { as much as possible }\end{array}$ & 8 & 28,57 & 21 & 75 & 25 & 89,28 & 26 & 92,85 \\
\hline $\begin{array}{l}\text { 6. Complete problem with syste- } \\
\text { matic and omprehensive }\end{array}$ & 8 & 28,57 & 20 & 71,42 & 24 & 85,71 & 24 & 85,71 \\
\hline $\begin{array}{l}\text { 7. Look for alternative- } \\
\text { alterna tive }\end{array}$ & 7 & 25 & 15 & 53,57 & 20 & 71,42 & 24 & 85,71 \\
\hline 8. Look for a reas on/ cause & 7 & 25 & 15 & 53,57 & 20 & 71,42 & 26 & 92,85 \\
\hline $\begin{array}{l}\text { 9. Look for statements which is } \\
\text { clear from a problem }\end{array}$ & 8 & 28,57 & 21 & 75 & 25 & 89,28 & 26 & 92,85 \\
\hline $\begin{array}{l}\text { 10. Remembering the primary/ } \\
\text { essential thing }\end{array}$ & 9 & 32,14 & 15 & 53,57 & 24 & 85,71 & 25 & 89,28 \\
\hline $\begin{array}{l}\text { 11. Use a credible source and } \\
\text { mention it }\end{array}$ & 8 & 28,57 & 20 & 71,42 & 24 & 85,71 & 24 & 85,71 \\
\hline $\begin{array}{l}\text { 12. Trying to be relevant to the } \\
\text { main idea }\end{array}$ & 9 & 32,14 & 15 & 53,57 & 24 & 85,71 & 25 & 89,28 \\
\hline $\begin{array}{l}\text { 13. Sensitive to feel ings, level of } \\
\text { knowledge, and ability level } \\
\text { of others }\end{array}$ & 8 & 28,57 & 21 & 75 & 25 & 89,28 & 26 & 92,85 \\
\hline Average & 7,69 & 25,29 & 17,61 & 62,91 & 21,30 & 82,69 & 25,81 & 90,37 \\
\hline
\end{tabular}


found that the students' critical thinking before the study was $25.29 \%$. After the third cycle or the application of blended learning with Google Classroom, it rose to $90.37 \%$. So, it can be stated that there was an increase in the capacity of students to think critically before and after the implementation of blended learning with Google Classroom (cycle 1 , cycle 2 , and cycle 3 ).

\section{CONCLUSION}

Based on the results of the research and discussion above, it can be concluded that the implementation of blended learning with Google Classroom could improve students' learning independence and critical thinking skills. However, beyond the successful implementation of the blended learning above, it is essential to realize that this strategy is relatively new and may only be popular during the COVID-19 pandemic in Indonesia, so there are many obstacles in its implementation. Lecturers must pay attention to adequate technical support and Internet connections to facilitate the implementation of this learning strategy. The readiness of technology and the stable Internet connection is necessary both for lecturers and students. Without adequate support, lecturers will prefer to use classical (conventional) and faceto-face learning. Also, lecturers need to consider the cost. To reduce the cost, lecturers can take advantage of free application offered on the Internet, such as Google Classroom, so they do not need to build complex and costly information systems.

\section{REFERENCES}

[1] E. Mahase, "China Coronavirus: what do we know so far" $B M J$, vol. 368, no. January, p. m308, 2020.

[2] E. Mahase, "Coronavirus: COVID-19 has Killed More People than SARS, and MERS Combined, Despite Lower Case Fatality Rate." British Medical Journal Publishing Group, 2020.

[3] K. M. K. Jiwa, "Konsep Tafakkur dalam Alquran dalam Menyikapi Coronavirus Covid-19."

[4] S. Subarto, "Momentum Keluarga Mengembangkan Kemampuan Belajar Peserta Didik di Tengah Wabah Pandemi Covid-19," 'ADALAH, vol. 4, no. 1, 2020.

[5] D. R. Nurlaeli and N. Nurwanti, "Kelekatan Ibu-Anak di Tengah COVID-19."

[6] A. R. I. Susanto et al., "Kajian Politik Hukum Pemerintah dalam Penanganan Pandemi Covid-19."

[7] A. Rusdiana, M. Sulhan, I. Zaenal, and A. U. Ahmad, "Penerapan Model POE2WE Berbasis Blended Learning Google
Classroom Pada Pembelajaran Masa WFH Pandemic Covid-19," pp. 1-10, 2020.

[8] F. Firman and S. Rahayu, "Pembelajaran Online di Tengah Pandemi Covid-19," Indones. J. Educ. Sci., vol. 2, no. 2, pp. 8189, 2020.

[9] H. Praherdhiono et al., Implementasi Pembelajaran Di Era Dan Pasca Pandemi COVID-19. Seribu Bintang, 2020.

[10] S. H. Thorik, "Efektivitas Pembatasan Sosial Berskala Besar di Indonesia Dalam Penanggulangan Pandemi Covid-19," 'ADALAH, vol. 4, no. 1, 2020.

[11] D. Jamaluddin, T. Ratnasih, H. Gunawan, and E. Paujiah, "Pembelajaran Daring Masa Pandemik Covid-19 pada Calon Guru: Hambatan, Solusi dan Proyeksi," LP2M.

[12] P. Punaji, "Pembelajaran Sistem Online: Tantangan dan Rangsangan," Maj. Ilm. Pembelajaran, vol. 3, no. 2, 2007.

[13] R.A. Mardiyah ${ }^{1}$ and R. N. Nurwati, "Dampak Pandemi Covid-19 Terhadap Peningkatan Angka Pengangguran Di Indonesia."

[14] K. Cotton, Teaching thinking skills. Northwest Regional Educational Laboratory, School Improvement Program, 1991.

[15] R. Kurniawati, "Pengembangan Media Blended Learning Berbasis Edmodo di Sekolah Menengah Kejuruan," Indones. J. Curric. Educ. Technol. Stud., vol. 3, no. 2, pp. 16-24, 2015.

[16] M. K. T. Rerung, "Students' Perception on Blended Learning in English Listening and Speaking Class," J. English Lang. Cult., vol. 9, no. 1, 2018.

[17] A. Alammary, J. Sheard, and A. Carbone, "Blended Learning in Higher Education: Three Different Design Approaches," Australas. J. Educ. Technol., vol. 30, no. 4, 2014.

[18] D. Yendri, "Blended Learning: Model Pembelajaran Kombinasi E-Learning dalam Pendidikan Jarak Jauh," Univ. Andalas. Diakses melalui http//fti. unand. ac. id/images/Blended Learning. pdf tanggal, vol. 28, 2011.

[19] Z. Hussin, S. Siraj, G. Darusalam, and N. H. M. Salleh, "Kajian Model Blended Learning dalam Jurnal Terpilih: Satu Analisa Kandungan," JuKu J. Kurikulum Pengajaran Asia Pasifik, vol. 3, no. 1, pp. 16, 2017.

[20] A. F. Amalia, "Penerapan Metode Blended Learning Berbasis TIK untuk Meningkatkan Pemahaman Konsep pada Matakuliah Listrik Magnet II," SOSIOHUMANIORA J. Ilm. Ilmu Sos. Dan Hum., vol. 3, no. 1, 2017.

[21] G. Sandi, "Pengaruh Blended Learning terhadap Hasil Belajar Kimia Ditinjau dari 
Kemandirian Siswa," J. Pendidik. dan Pengajaran, vol. 45, no. 3, 2012.

[22] W. S. Ambar Ningsih, W. Suana, and N. Maharta, "Pengaruh Penerapan Blended Learning Berbasis Schoology Terhadap Kemampuan Berpikir Kritis Siswa," Konstan - J. Fis. Dan Pendidik. Fis., vol. 3, no. 2, pp. 85-93, 2018.

[23] R. Setiawan, D. Mardapi, A. Pratama, and S. Ramadan, "Efektivitas Blended Learning dalam Inovasi Pendidikan Era Industri 4.0 pada Mata Kuliah Teori Tes Klasik," J. Inov. Teknol. Pendidik., vol. 6, no. 2, pp. 148-158, 2019.

[24] I. M. Sujana, U. Waluyo, A. Arifuddin, and H. Soepriyanti, "Pengembangan 'Content' Google Classroom Untuk Guru Dan Mahasiswa Bahasa Inggris Kota Mataram," J. Pendidik. dan Pengabdi. Masy., vol. 2, no. 4, 2019.

[25] S. Supriadi and M. Mustafa, "Pengembangan Model Blended Learning
Berbasis Google Classroom Pada Mata Kuliah Rekayasa Sistem Audio," in Seminar Nasional LP2M UNM, 2019.

[26] N. E. Sari and D. Suryana, "Thematic PopUp Book as a Learning Media for Early Childhood Language Development," JPUD J. Pendidik. Usia Dini, 2019.

[27] S. Kemmis and M. Taggart, "R.(2013)," Action Res. Plan. Doing Crit. Particip. Action Res.

[28] N. Kristiani and Z. K. Prasetyo, "Keefektifan Pembelajaran Metematika Melalui Penggunaan Media Benda Konkret Pada Kelas V Sd Timuran," J. Prima Edukasia, 2016.

[29] S. Arikunto and S. Suhardjono, "Penelitian Tindakan Kelas." Jakarta: Bumi Aksara, 2006.

[30] E.Mulyasa,Menjadi Guru yang Profesional:Menciptakan Pembelajaran yang Kreatif dan Menyenangkan, Bandung: Rosdakarya, 2006. 